\title{
İ̧̧birlikli Öğrenme-Öğretme Yaklaşımına Yönelik Bir Derleme Çalışması
}

\section{A Compilation Study on The Collaborative Learning-Teaching Approach}

\author{
Seher ÇETINKAYA , Doç. Dr., Ordu Üniversitesi, seherbayat@odu.edu.tr
}

Tuğçe DURMUŞ ${ }^{\mathrm{D}}$, Doktora Öğrencisi, Ordu Üniversitesi, tugcedurmus@odu.edu.tr

Çetinkaya, S. ve Durmuş, T. (2021). İşbirlikli öğrenme-öğretme yaklaşımına yönelik bir derleme çalışması. Batı Anadolu Ĕgitim Bilimleri Dergisi, 12(2), 630-649.

Geliş tarihi:08.10.2021 Kabul tarihi:03.11.2021

Yayımlanma tarihi:28.12.2021

Öz. Araştırmanın amacı, 2015-2021 yılları arasında ilkokulda işbirlikli öğrenme-öğretme yaklaşımıyla hazırlanmış makale ve tezleri bir araya getirip "Yayın Yılı ve Yayın Türü”, "Disiplin Alanları”, "Sınıf Düzeyi”, “işbirlikli Öğretim Teknikleri", "Amaçları", "Sonuçları" ve "Önerileri” değişken göre inceleyerek sistematik bir derleme çalışması yapmaktır. Sistematik derleme çalışmaları belli ölçütler çerçevesinde alanyazın taraması yapılarak ulaşılan mevcut araştırmalardan seçilen makale ve tezlerin derinlemesine sentezlendiği bir araştırma yöntemidir. Bu doğrultuda araştırma sistematik derleme çalışması olarak yapılandırılmış ve bu çerçevede incelenmiştir. Öncelikle derlemesi yapılacak makale ve tezlerin ölçütleri yansıtma durumları araştırmacılar tarafından belirlenmiş, dâhil edilecek makale ve tezler için "TR dizinde yayınlanma", "YÖK Ulusal Tez Merkezinde tam metnine ulaşılma", "2015-2021 yılları arasında yayınlanmış olma" kriterlerine göre çalışmanın kapsamı daraltılmıştır. İlgili kriterlere göre 8'i makale, 10'u lisansüstü tez olmak üzere toplam 18 yayın incelenerek çalışma yürütülmüştür. Seçilen makale ve tezlerin her biri yıllara göre farklı bir biçimde kodlanmıştır. Araştırma kapsamında makale ve tezler içerik analizi yöntemiyle analiz edilmiştir. Elde edilen bulgular sonucunda çalışmalar amaçlarına göre incelendiğinde "beceri", "akademik başarı" ve "tutum" ve "diğer" olmak üzere dört temaya ulaşılmıştır. Araştırma sonuçlarına göre, "Beceri" temasında bir tez hariç diğer makale ve tezlerin tamamının işbirlikli öğrenme-öğretme yaklaşımının anlamlı farklılıkla beceri/tutum akademik başarı üzerinde olumlu yönde katkı sağladığı, işbirlikli öğrenme-öğretme yaklaşımına ilişkin olumlu metaforların üretildiği ve ilkokul 4. sınıf düzeyinde bir "Bütünleşme Ölçeği" geliştirildiği sonucuna ulaşılmıştır. Araştırmada ulaşılan sonuçlar doğrultusunda ilkokul düzeyinde işbirlikli öğrenme yaklaşımının öğrencilerin sosyal becerilerine etkilerinin incelendiği çalışmaların yapılması önerilebilir.

Anahtar Kelimeler: İşbirlikli öğrenme-öğretme yaklaşımı, İşbirlikli öğretim teknikleri, illkokul, Sistematik derleme.

\begin{abstract}
The study aim of the research is to bring together the articles and theses prepared with the cooperative learning-teaching approach in primary school between the years 2015-2021, "Publication Year and Publication Type", "Disciplinary Fields", "Class Level", "Collaborative Teaching Techniques", "Aims", " It is to make a systematic review study by examining the results according to the parameters of "Recommendations" and "Recommendations". Systematic compilation studies are a research approach in which the findings from selected articles and theses are synthesized in depth, and existing researches are identified by scanning the literature using specific criteria. The research was constructed as a systematic review study and investigated within this framework in this approach. First and foremost, the researchers identified the research's goal as well as the criteria for the papers and theses that would be assembled. The scope of the project has been reduced. A total of eighteen publications, eight of which were articles and ten of which were postgraduate theses, were evaluated and the study was carried out according to the applicable criteria. The articles and theses chosen for this study were categorized by year and type, and each publication was classified differently. Articles and theses were classified according to similar and dissimilar features within the scope of the study and
\end{abstract}


examined using the content analysis approach in accordance with the study's aim. As a result of the findings, when the studies were examined according to their objectives, four themes were reached, namely "Skill", "Academic Success", "Attitude" and "Other". According to the results of the research, all of the articles and theses, except for one thesis, on the theme of "Skill", showed that the cooperative learning-teaching approach contributed positively to the academic achievement of the skill/attitude with a significant difference, positive metaphors about the cooperative learning-teaching approach were produced, and a 4th grade level of primary school. The "Integration Scale" was developed as a result of the research. According to the findings of the study, investigations exploring the effects of cooperative learning on students' social skills at the primary school level should be conducted.

Keywords: Cooperative learning-teaching approach, Cooperative teaching techniques, Primary school, Systematic review. 


\section{Extended Abstract}

Introduction. Individuals who use a cooperative learning-teaching approach keep coming up with their own original ideas. Individually and socially, they are developing at this stage. Because of their need to finish the group activity, the cooperative learning and teaching approach, which may be used at any grade level and in any subject, leads to individuals' positive dependence on one another. Cooperative learning-teaching is an innovative learning-teaching approach that can be used to develop learning quality, provide individuals with the opportunity to learn many social skills such as leadership, joint decision-making, communication, building mutual trust, and solving in-group problems, and can be adapted to all learning environments. In this context, the research will investigate Turkish papers and theses published at the primary school level between 2015 and 2021 that were prepared with a cooperative learning-teaching strategy. Collaborative learning-teaching approach students play a role in the process of constantly generating ideas and transferring their ideas to their friends. In addition, it gives them the opportunity to exhibit more positive behaviors in academically, by making them constantly active in the classroom environment and in solving problems. It supports socially with its strong social support system, and psychologically with the principles of positive dependency and individual responsibility.

Method. This study is a systematic review study in the compilation study sub-pattern that looks at articles and theses that use a cooperative learning-teaching approach. systematic review studies are an important takes its place in the literature as a research method. Systematic compilation studies are carried out within a certain protocol. In addition, systematic review studies are studies that require an in-depth examination of research on a particular subject. The checklist developed by the researchers specified the research's aim and reflection of the criteria for the articles and theses to be compiled, as well as the processes to be followed in the research process and the stages of the research. The scope of the study was limited to include only articles and theses that met the criteria of "publishing in the TR index," "reaching the complete text in the Yök National Thesis Center," and "publishing between the years 2015-2021". It was done as a backward review of research publications and theses that were relevant to cooperative learning and teaching. The research was conducted by looking at eight papers and 10 postgraduate theses in this context. The data were examined using content analysis for the objective of the study.

Results. According to the findings of the study, more studies on the cooperative learning-teaching approach have been published in articles and theses in recent years; research has been conducted with 4th grade students at the most as the teaching level, and the jigsaw method is the most preferred among the teaching techniques. In general, the cooperative learning-teaching approach provides students with "Skill, Access, and Opportunity." The variables "Reading Comprehension, Reflective Thinking, Problem Solving, Singing, Rhythm, Reach, Persistence, Creative Writing" aimed at the theme of Persistence have a positive effect, and the researchers recommend that different studies on the cooperative learning-teaching approach the primary school level be conducted. In summary, it has been revealed as a common emphasis that publications designed with a cooperative learning-teaching approach contribute positively to the basic competencies and skills of students such as academic success, motivation, attitude and self-efficacy.

Discussion and Conclusion. When the articles and theses included in the study are categorized by year, it can be noted that the most widely published disciplines in elementary schools using a cooperative learning approach were in 2015 and 2019, The most studied discipline was "Mathematics," and the "Jigsaw Technique" was devised the most, followed by "Skill," "Academic achievement," "Persistence," and "Attitude" under the cooperative learning-teaching strategy's theme of "Skill, Reach, and Persistence", "Reading Comprehension, Reflective Thinking, Problem 
Solving, Singing, Rhythm Keeping, Reach, Persistence, Creative Writing" were among the experimental tests conducted. It was determined that studies on the development of "skills" and their impact on achievement and long-term persistence should be included in additional literature. The research shows that the skill categories are primarily concerned with improving academic accomplishment, with the development of social or affective skills receiving less attention. Studies should be conducted in this area to increase student's social and affective abilities in the cooperative learning approach at the elementary school level. The study group decided to concentrate on the fourth grade level. The need of conducting experimental investigations with a cooperative learningteaching approach for kids in the first grade of elementary school is highlighted. Furthermore, longterm research using a cooperative learning-teaching approach are shown to be limited.

\section{Giriş}

Eğitim-öğretim süreci çağdaş yaklaşımlardan biri olan yapılandırmacı yaklaşımla birlikte çeşitli yöntem ve tekniklerle bireyin zihninde yapılandırma sürecini niteliksel olarak artırmıştır. Bu yenilikçi anlayışla öğrenme ortamlarının, geliştirilen öğretim programlarının etkisiyle, bireyin öğrenme sürecine aktif olarak katılmasına imkân sağlayan işbirlikli öğrenme ve öğretme yaklaşımı önem kazanmıştır (Driscoll, 2012; Özden, 2021; Taş ve Akoğlu, 2020). İşbirlikli öğrenme-öğretme yaklaşımı, bireylerin birlikte çalışarak aynı amaca ulaşabilmek için, bireysel ve grup olarak sorumluluk alabildikleri, olumlu bağlılık kurabilme becerisi geliştirdikleri, grup etkileşiminde bulunabildikleri, öğreneni merkeze alan ve belirli ilkelere dayanan, yapılandırılmış küçük grup çalışmalarıdır (Dirik, 2015). Öğrenmeyi en üst seviyede gerçekleştirmek için farklı yeteneklere sahip bireylerin oluşturduğu karma gruplarda öğrencilerin birbirlerinin öğrenmelerinden sorumlu olması akademik başarı üzerinde, grup içi ve gruplar arası etkileşimin yoğun olması da sosyal becerileri geliştirme noktasında olumlu yönde katkı sağlar. İşbirlikli öğrenme- öğretme yaklaşımıyla etkin olan bireyler, kendilerine özgü fikirler oluşturur. Bu aşamada ise bireysel ve sosyal olarak gelişim gösterir (Johnson ve Johnson, 1999; Slavin, 1990). Her sınıf düzeyinde ve her konu üzerinde uygulanabilen işbirlikli öğrenme ve öğretme yaklaşımı, bireylerin grup görevini tamamlamak için birbirlerine duydukları ihtiyaçtan dolayı olumlu bağımlıık kurmalarına katkı sağlar. Ayrıca grup başarısı ve bireysel başarı olanağı sağlayarak bireylerin birbirlerinin öğrenme çabalarına destek vermelerine, birbirlerini öğrenmeye teşvik etmelerine katkı sağlar (Johnson ve Johnson, 2009).

İşbirlikli öğrenme ve öğretme yaklaşımı, grupların etkili bir şekilde çalışabildiği, öğrencilerin liderlik, karar verme, güven oluşturma, çatışma yönetimi gibi sosyal becerileri kazanmasına olanak sağlayan ve eğitimde ihmal edilmiş duyuşsal özelliklerin kazandırılması sorununa da çözüm getiren bir yaklaşımdır (Doymuş, Şimşek ve Şimşek, 2005; Johnson, Johnson ve Holubec, 1991; Slavin, 1980). İşbirlikli öğrenme-öğretme yaklaşımı bireyi dışarıdan içeriye değiştirmeyi hedeflediği için (Joyce vd., 2009), sosyal etkileşim kurabilme, gözlem yapabilme, düzenli ve uyumlu hareket edebilme, arkadaşlık bağı kurabilme becerilerini odağına alır (Cartwright, 1993). Her sınıf seviyesinde uygulanabilen, birçok araştırmacı tarafından etkisi sınanan ve yöntemlerinin deneysel karşılaştırmalarının yapıldığı yaygın bir yaklaşım olarak işbirlikli öğrenme-öğretme yaklaşımı (Bayrakçeken, Doymuş ve Doğan, 2013), birçok teknik kullanılarak sınıflarda uygulanır. Bu tekniklerin ortak paydası ise öğrenenlerin küçük guruplar veya takımlar hâlinde çalışarak birbirlerinin öğrenmelerinden sorumlu olmalarıdır. Ayrıca yaklaşıma yönelik geliştirilen tüm yöntem-teknikler, öğretmenin yüksek-ortalama-düşük başarı düzeyindeki öğrencilerden, erkek ve kızlardan, akademik olarak avantajlı sınıf arkadaşları yanında, temelde akademik olarak dezavantajlı olan öğrencilerden oluşan 4 ile 6 üyelik gruplara ayrılarak sınıf içerisinde heterojen grupların oluşmasını temel alır (Açıkgöz ve Güngör, 206; Bayrakçeken, Doymuş ve Doğan, 2013; Kara, 2016; Kartal ve Özbek, 2017). Özetle işbirlikli öğrenme-öğretme yaklaşımı, öğrenmenin niteliğini artırmak üzere kullanılabilecek, bireylere, liderlik, birlikte karar verme, iletişim, karşılıklı güveni inşa etme ve grup içi problemleri çözme gibi birçok sosyal beceriyi de edinme fırsatı 
sağlayan, tüm öğrenme ortamlarına uyarlanabilen yenilikçi bir öğrenme-öğretme yaklaşımıdır (Johnson, Johnson ve Holubec, 2016).

Ilköğretimden bu yana tüm kademelerin ortak hedefi öğrencilere bilimsel bilginin doğru ve kalıcı bir biçimde kazandırımasıdır. Ancak öğrencilerin gelecekteki yaşamlarına akademik başarının yanında iyi bir dost edinebilme, sosyal beceriler geliştirebilme ve çevresiyle olumlu bağ kurabilme gibi becerilerin de kazandırılması gerekmektedir. Bilindiği üzere işbirlikli öğrenme-öğretme yaklaşımı ilkokuldan itibaren öğrenim gören öğrencilerin akranlarıyla birlikte çalışarak ürünler ortaya koyarken edindiği sosyal tecrübelerini paylaşma cesareti verir, akademik başarıly paralel olarak bireyin sosyalleşmesine olanak sağlar (Gelici ve Bilgin, 2011; Şimşek, Şimşek ve Doymuş 2006; Arısoy ve Tarim, 2013; Yıldız, Şimşek ve Ağdaş, 2017).

Çubukçu (2020) işbirlikli öğrenme-öğretme yaklaşımının çıktılarını aşağıdaki gibi özetlemektedir.

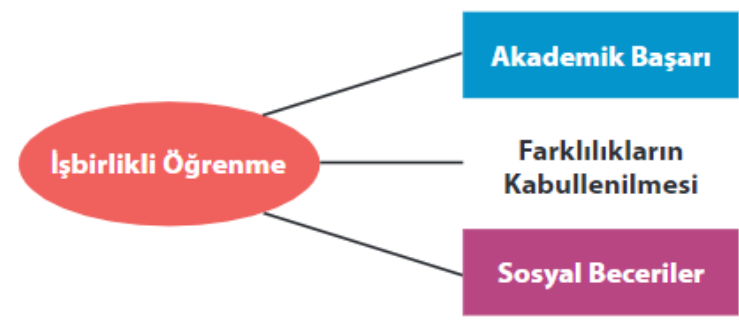

Şekil 1. İ̧birlikli öğrenme-öğretme yaklaşımının çıktıları

Işbirlikli öğrenme-öğretme yaklaşımının öğrencileri, sürekli fikir üretme ve fikirlerini arkadaşlarına aktarma sürecinde rol oynayarak (Doğan, Doymuş, Gök, ve Karaçöp, 2009) akademik yönden, sınıf ortamlarında sürekli etkin hale getirerek ve sorunların çözümünde daha olumlu davranışlar sergilemelerine fırsat vererek güçlü sosyal destek sistemiyle (Cohen ve Willis, 1985; Demirtaş, 2010; Gut ve Safran, 2002; Koçak, 2008) sosyal yönden, olumlu bağımlılık ve ferdi sorumluluk ilkeleri ile psikolojik yönden (Goodwin, 1999) desteklediği bilinmektedir.

Johnson ve diğerleri (1991) işbirlikli öğrenme-öğretme yaklaşımının temel yapıtaşlarını;

1) Üyelerin ortak bir hedefe ulaşmak için birbirlerine bağımlılığı (Takımın olduğu yerde pozitif karşılıklı bağımlıık)

2) Grup üyelerinin uygulama sürecinde kendi payına düşeni yapmaktan sorumlu olması (Bireysel hesap verebilirlik

3) Grup çalışmasının bir kısmı bir birey üzerinde yapılabilse de, teşvik edici etkileşimin temelde, her grubun etkileşimli bir süreçle gerçekleştirilmesi (Yüz yüze)

4) Öğrencilere fırsat verildiğinde işbirlikçi becerilerin uygun kullanımıyla güvenin oluşturulması

(Liderlik, karar verme, iletişim ve çatışma yönetimi becerileri)

5) Grup üyelerinin grup oluşturduğu takım olarak performanslarının değerlendirilmesi periyodik olarak gerçekleşir (grupla değerlendirme) olarak ifade etmiştir.

İşbirlikli öğrenme-öğretme yaklaşımına uygun olarak geliştirilen stratejiler yüz yüze veya çevrimiç̧i eğitim ortamlarında, farklı disiplin alanlarında kullanılabilir. Bu durum derin bir öğrenme süreci gerçekleşirken öğrencide karar verme, problem çözme ve geliştirme gibi becerileri kazanmaya teşvik eder, aktif olarak sürece dahil olan öğrenci zaman içerisinde gerekli akademik ve sosyal becerileri kazanmış, problemleri işbirliğine dayalı olarak çözmüş olur (Garrison ve Cleveland-Innes, 
2005; Mason ve Watts, 2012; Tsay ve Brady, 2010). ilkokulda işbirlikli öğrenme-öğretme yaklaşımına yönelik uygulamaların öğrenmenin etkililiği için gerekli olduğu, grup hedeflerinin veya grup ödüllerinin kullanılmasının grup üyelerinin başarı sonuçlarını geliştirirken motivasyonun arttı̆̆ı bilinmektedir (Slavin, 2016). Bu becerilerin kazandırılmasında kilit bir model olan işbirlikli öğrenmeöğretme yaklaşımıyla tasarlanmış tekniklerden en yaygın kullanılan teknikler: Jigsaw, Birlikte Öğrenme, Grup Araştırması (GA), Öğrenci Takım-Başarı Bölümleri ve Takımlar-Oyunlar-Turnuva (Slavin, 2016), Takım Temelli Öğrenme (TBL), Okuma-Yazma-Uygulama (OYU) olarak sıralanabilir.

İşbirlikli öğrenme-öğretme yaklaşımı, öğrencilerin benlik saygısını geliştiren ve öğrenme sürecine aktif katılımını sağlayan, alternatif değerlendirme yöntemlerini işe koşan (Johnson, Johnson ve Taylor, 1993; Kagan, 1986; Panitz, 1999) bir yaklaşım olduğu için çok fazla sayıda araştırma konusu olmaktadır.

İşbirlikli öğrenme-öğretme yaklaşımına yönelik alanyazın incelendiğinde; dünya üzerinde öz düzenleme (Rojas-Drummond, Hernández, Vélez ve Villagrán, 1988; Rowntree, 2018), motivasyon (Fernandez-Rio, Sanz, Fernandez-Cando ve Santos, 2017; Hortigüela Alcalá, Hernando Garijo, PerezPueyo ve Fernandez-Rio, 2019; Sulisworo ve Suryani, 2014), duygusal zeka ve akademik başarı arasındaki bağlantı (Carlos Torrego-Seijo, Caballero-García ve Lorenzo-Llamas, 2021), kişilerarası davranış ve destekleyici iletişim (Dendup ve Onthanee, 2020; Lan, Liu ve Baranwal, 2020; Maelasari, 2017; Safitri, Dwijanto ve Yusuf, 2020) ve sosyal ve duygusal öğrenme (Pawattana, Prasarnpanich ve Attanawong, 2014; Rahayu, ve Nugraha, 2018) konuları üzerinde araştırmalar yoğunlaşırken, ülkemizde işbirlikli öğrenme-öğretme yaklaşımının akademik başarı, tutum, kavramsal değişim üzerindeki etkilerine yönelik meta-analiz çalışmaları (Bakioğlu ve Göktaş, 2020; Batdı, 2014; Camnalbur ve Mutlu Bayraktar, 2018; Capar ve Tarim, 2015; İleri, Selvi ve Köse, 2020; Şenol ve Yılmaz, 2013; Tuncer ve Dikmen, 2017; Turgut, 2018), sınıf ortamında uygulanmasına, eğitim ortamına faydalarına ve yöntemlerin uygulanma şekillerine yönelik (Şimşek, Şimşek ve Doymuş, 2006, 2008) derleme çalışmaları mevcuttur. Ancak daha özel bir bakış açısıyla bakıldığında ilkokul düzeyinde işbirlikli öğrenme-öğretme yaklaşımıyla hazırlanmış sistematik bir derleme çalışmasına rastlanmamıştır. Birçok açıdan değerlendirilen bu yaklaşıma yönelik dağınık bir şekilde bulunan araştırmaların belirli ölçütlere göre kategorize edilerek taranması, irdelenmesi, sonraki araştırmalara ışık tutması bakımından önemlidir. Bu durum alanyazında kaydedilen ilerlemeler, yaşanması muhtemel aksaklıklar, konunun kültürel özelliklere göre birbiriyle ilişkisi, çeşitliliği ve daha pek çok boyutun bir bütün olarak ortaya çıkarılmasına olanak sağlar. Ayrıca ilkokul düzeyinde işbirlikli öğrenme-öğretme yaklaşımıyla tasarlanmış çalışmaların bir araya getirilerek belli bir açıdan incelenmesi; işbirlikli öğrenme-öğretme yaklaşımının gelecekte uygulanması ön görülen çalışmalarda araştırmacılara ve işbirlikli öğrenme-öğretme yaklaşımını ders ve öğretim içeriklerine uyarlama ve uygulama sürecinde öğretmenlere rehber niteliğinde olacağı düşünülmektedir. İşbirlikli öğrenmeöğretme yaklaşımıyla tasarlanmış araştırmalarda kullanılan işbirlikli öğretim tekniklerinin incelenmesi araştırmacılara ve öğretmelere bütüncül bir bakış açısı sunarken, öğrenci başarısı/tutumu/erişişine ve öğretim sürecine etkilerinin bir bütün halinde ortaya koyulması noktasında da alana katkı sağlayacağı düşünülmektedir. Bu kapsamda araştırma 2015-2021 yılları arasında işbirlikli öğrenmeöğretme yaklaşımıyla ilkokul düzeyinde yayınlanmış Türkçe makale ve tezleri inceleyerek bir derleme çalışması yapmaktır.

\section{Yöntem}

\section{Araştırma modeli}

İşbirlikli öğrenme-öğretme yaklaşımıyla tasarlanmış makale ve tezlerin incelendiği bu araştırma derleme çalışmalarının alt deseninde sistematik derleme çalışmasıdır. Eğitim 
araştırmalarında uzun yıllar bir yöntem olarak kullanılan sistematik derleme çalışmaları, belirli bir konuda yapılan bütün araştırmaların incelenerek elde edilen bilgi ve deneyimlerin alanyazına dayalı olarak araştırmacılar tarafından paylaşıldığı yol gösterici bir yöntemdir (Karaçam, 2013; Torgerson, 2003). Sistematik derleme çalışmalarında belli bir konu ekseninde araştırma yürütülür, konuya ilişkin detaylı ve geniş bir biçimde tarama gerçekleştirilir, araştırmacı tarafından belirlenen dışlanma ve dâhil edilme kriterleri kullanılarak bilimsel incelemelerle elde edilen bulgu ve sonuçlar sentez edilir ve raporlanır (Aslan, 2018; Needleman, 2002).

\section{Veri toplama süreci}

Araştırma sistematik derleme çalışması olarak yapılandırılmış, öncelikle araştırmanın amacını ve derlemesi yapılacak makale ve tezlerin ölçütleri yansıtma durumları, araştırma sürecinde izlenecek adımlar ve araştırmanın aşamaları araştırmacılar tarafından hazırlanan kontrol listesiyle belirlenmiştir. Hazırlanan sistematik tarama süreci ve kontrol listesi aşağıda şekillerle sunulmuştur.
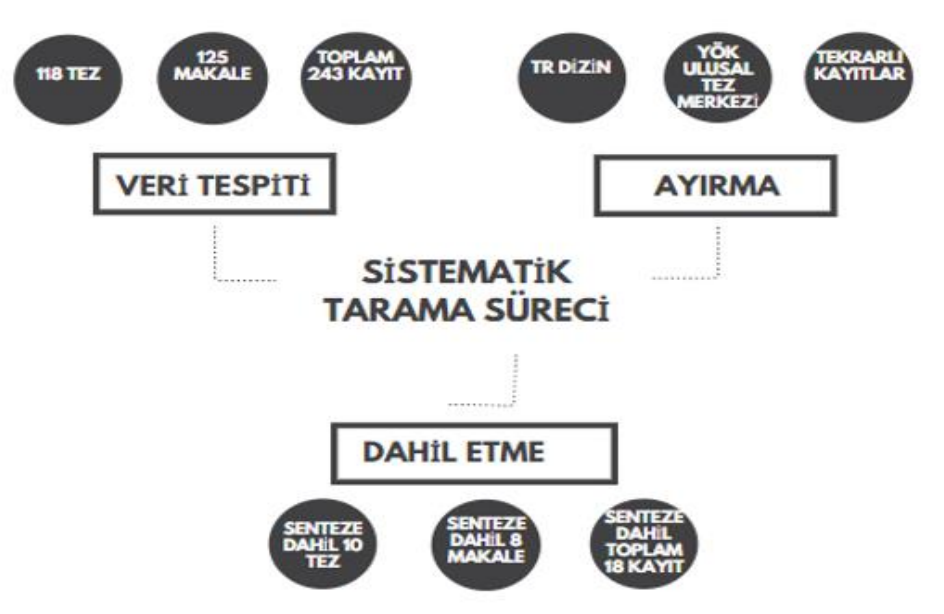

Şekil 2. Sistematik tarama süreci

Araştırmaya dâhil edilecek makale ve tezler için "TR dizinde yayınlanma", "YÖK Ulusal Tez Merkezinde tam metnine ulaşılma", "2015-2021 yılları arasında yayınlanmış olma" kriterlerine göre çalışmanın kapsamı daraltılmıştır. İşbirlikli öğrenme-öğretme yaklaşımına yönelik daha derinlemesine inceleme yapmak için yayın yılı daraltılmış, altı yıl içerisinde yayınlanan çalışmalarla sınırlandırılarak güncel yayınlardan geriye dönük olarak araştırma makalelerinin ve tezlerin taranması gerçekleştirilmiştir. Veri tabanlarında arama gerçekleştirilirken toplu tarama yapılmış, Türkçe dilde "İ̧̧̧irlikli Öğrenme-Öğretme Yaklaşımı", "Iş̧irlikli Öğretim Teknikleri”, "illkokul” anahtar sözcükleriyle tarama yapılmış, ardından kaynakların özetleri incelenerek tam metnine ulaşılabilen makale ve tezler belirlenmiştir. Ardından araştırma işbirlikli öğrenme-öğretme yaklaşımına dair belirlenen makale ve tezler bir alan uzmanı ile görüşülerek inceleme kriterleri oluşturulmuş, bu bağlamda "Yayın Yılı ve Yayın Türü", "Disiplin Alanları", "Sınıf Düzeyi”, "Işbirlikli Öğretim Teknikleri”, "Amaçlar”, "Sonuçlar” ve "Öneriler" değişkenlerine göre temalar ortaya çıkarılmıştır. Illgili kriterlere göre İşbirlikli öğrenmeöğretme yaklaşımına yönelik 118 adet tez çalışmasına ve 125 adet makaleye ulaşılmıştır. Ulaşılan makale ve tezler titizlikle irdelenmiş, belirlenen değişkenlere uygun olmayan makale ve tezler elenmiştir. Makale ve tezler dâhil edilme ve dışta kalma kriterlerine uyma koşuluna göre ve araştırmanın amacına uygunluğuna göre araştırmaya dâhil edilmiştir. Araştırmanın amacına yönelik olarak seçilen makale ve tezler, yıl ve türlerine göre gruplandırılmış ve her biri farklı bir biçimde 
kodlanmıştır. Ayrıca kongrelerde sunulan bildiriler, kitaplar, raporlar ve sadece özetine ulaşılabilen makaleler bu sistematik derlemeye dâhil edilmemiştir. Bu kapsamda sekiz makale ve on lisansüstü tez incelenerek çalışma yürütülmüştür.

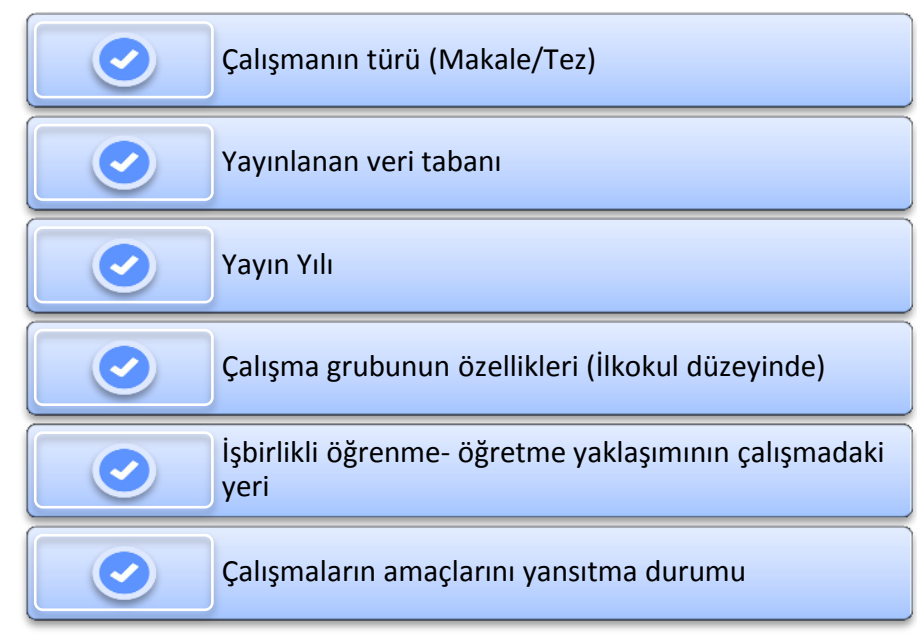

Şekil 3. Kontrol listesi

Makale ve tezlerin şekil 3'te sunulan kontrol listeleri ile çalışmaya dâhil edilip edilmemesine karar verilmiştir. Araştırmaya dâhil edilen bütün çalışmaların bölümleri detaylı bir şekilde incelenmiş bir çalışmaya ait özet veriler bilgisayar ortamına kaydedilmiştir. Araştırmada kullanılan makale ve tezler daha rahat analiz edilebilmesi her bir çalışma için en eski yayından başlayarak makaleler için " $\mathrm{M}_{1}, \mathrm{M}_{2} \ldots \mathrm{M}_{8}$ ", tezler için " $\mathrm{T}_{1}, \mathrm{~T}_{2} \ldots \mathrm{T}_{10}$ " şeklinde kodlanmış ve analiz sonucuna ait bulgular raporlanmıştır. Ayrıca incelenen makaleler araştırmanın şeffaflığını korumak adına Ek1'de sunulmuştur.

\section{Veri analizi}

Sistematik derleme çalışmaları analiz edilirken, elde edilen verilerin bütününün belirli kategorilerle benzer ve farklııklarına göre alt kümelere ayrılmasını ve ortak noktalarının belirlenmesini hedefler ve bu yönüyle araştırmacılara verileri sentezlerken karşılaştırma yapma fırsatı sağlar (Higgins, Thomas, Chandler, Cumpston, ve Li, 2019). Analiz sürecinde dikkat edilmesi gereken diğer bir husus ise tarama sürecinde geliştirilen kontrol listesinin sistematik bir incelemenin eksiksiz raporlanmasını sağlamak için kullanılması, sonuçlara dayalı olarak alt başıklar kullanarak verilerin yapılandırılması ve anlatı sentezi ile ayrıntılı bir biçimde açıklanmasıdır (Sobieraj ve Baker, 2021). Araştırma sürecinde elde edilen verilerin analizi sürecinde önemli noktaların vurgulandığı, tema ve kategorilerle ilgili unsurların açıklandığı, kavram ve ilişkilerin belirlenerek ele alınan konu hakkında derinlemesine bilginin elde edildiği analiz yöntemlerinden biri de içerik analizidir (Patton, 2014; Yıldırım ve Şimşek, 2018). Araştırmanın amacına yönelik olarak veriler içerik analiziyle analiz edilmiştir. Araştırmaya dâhil edilen makale ve tezlerin her biri hazırlanan kontrol listesinden hareketle Yayın Yılı, Yayın Türü, Amaç, Disiplin Alanı, Kademe, Uygulanan Öğretim Teknikleri, Bulgular, Sonuç ve Öneriler değişkenlerine uygun olarak temalara ayrılmış ve her bir temayı temsil edecek kategoriler belirlenerek uygun başlıklara yerleştirilmiştir. Elde edilen veriler bu başlıklar altında tablolaştırııı ortak bir anlam ilişkisi içerisinde benzerlik ve farklılıklarına göre gruplara ayrımıştır. Bu bağlamda çalışmalar tablolar hâlinde sunulmuştur. Verilerin tablolar halinde sunulmasının amacı, çalışmanın okurlarına organize edilmiş bilgi kaynağına ulaşma imkânı tanımasıdır. Tabloda frekanslara, makale ve tezlerin kodlarına yer verilmiştir. Verilerin kodlanmasında iki araştırmacı birlikte çalışmış, kodlama tutarlılı̆ı̆ süreçte birlikte tartışarak sağlanmıştır. Ayrıca bir 
alan eğitimi uzmanından temaların oluşturulmasında ve kategorilerin belirlenmesinde görüş alınmış, kodlamalardaki farklı görüşler tartışılıp ortak fikir doğrultusunda kodlamalara son şekli verilmiştir. Araştırmacıların analizleri ile alan uzmanı arasında uyuşma sağlandığı görülmüştür. Bu sayede çalışmanın güvenirliği sağlanmaya çalışılmıştır.

\section{Bulgular}

Tablo 1.

Çalışmaya dâhil edilen makale ve tezlerin yayın yılı ve yayın türü

\begin{tabular}{lrrrr}
\hline Yayın Yılı & $\begin{array}{r}\text { Makale } \\
\text { Kod }\end{array}$ & $\boldsymbol{f}$ & $\begin{array}{r}\text { Yüksek Lisans Tezi } \\
\text { Kod }\end{array}$ & $f$ \\
\hline 2015 & $\left(\mathrm{M}_{1}, \mathrm{M}_{2}, \mathrm{M}_{3}\right)$ & 3 & $\left(\mathrm{~T}_{1}, \mathrm{~T}_{2}, \mathrm{~T}_{3}, \mathrm{~T}_{4}\right)$ & 3 \\
2016 & - & 0 & 0 & - \\
2017 & - & 1 & $\mathrm{~T}_{5}$ & 1 \\
2018 & $\mathrm{M}_{4}$ & 2 & $\mathrm{~T}_{6}$ & 1 \\
2019 & $\mathrm{M}_{5}, \mathrm{M}_{6}$ & 2 & $\mathrm{~T}_{7}, \mathrm{~T}_{8}, \mathrm{~T}_{9}$ & 3 \\
2020 & $\mathrm{M}_{7}, \mathrm{M}_{8}$ & $\mathrm{~T}_{10}$ & 1
\end{tabular}

İşbirlikli öğrenme yaklaşımıyla ilkokulda en yoğun çalışmaların gerçekleştirildiği yılın 2015 olduğu ve bu yıla ait üç makale $\left(M_{1}, M_{2}, M_{3}\right)$, üç yüksek lisans tezi $\left(T_{1}, T_{2}, T_{3}, T_{4}\right)$ yer aldığı görülmektedir. 2016 yılına ait bir çalışmaya rastlanmamakta, 2017 yılında ise bir yüksek lisans tezi $\left(T_{5}\right)$ yer almaktadır. 2018 yılına ait bir yüksek lisans tezi $\left(T_{6}\right)$, bir makale $\left(M_{4}\right)$ yayınlandığı görülmektedir. Yine 2019 yılına ait üç yüksek lisans tezi $\left(T_{7}, T_{8}, T_{9}\right)$, iki makale $\left(M_{5}, M_{6}\right)$ yer almaktadır. Son olarak çalışmalar incelendiğinde 2020 yılına ait bir yüksek lisans tezi $\left(T_{10}\right)$, iki makale $\left(M_{7}, M_{8}\right)$ yayınlandığı görülmektedir.

Tablo 2.

Çalışmaya dâhil edilen makale ve tezlerin uygulandığı disiplin alanlarına ilişkin bulgular

\begin{tabular}{lrr}
\hline Disiplin alanları & Kod & $f$ \\
\hline Matematik & $\mathrm{T}_{1}, \mathrm{~T}_{3}, \mathrm{M}_{4}, \mathrm{M}_{7}$ & 4 \\
Türkçe & $\mathrm{T}_{7}, \mathrm{M}_{1}, \mathrm{M}_{2}$ & 3 \\
Fen Bilimleri & $\mathrm{T}_{5}, \mathrm{~T}_{8}$ & 2 \\
Hayat Bilgisi & $\mathrm{T}_{10}, \mathrm{M}_{3}$ & 2 \\
Müzik & $\mathrm{T}_{2}, \mathrm{M}_{6}$ & 2 \\
Sosyal Bilgiler & $\mathrm{T}_{6}$ & 2 \\
Din Kültürü & $\mathrm{T}_{4}$ & 1 \\
Metaforik Algı & $\mathrm{M}_{5}$ & 1 \\
Yaratıcı Yazma & $\mathrm{T}_{9}$ & 1 \\
Ölçek Geliştirme & $\mathrm{M}_{8}$ & 1 \\
\hline
\end{tabular}

İ̧̧birlikli öğrenme yaklaşımıyla tasarlanmış çalışmaların disiplin alanları incelendiğinde; matematik dersinde yoğunlaşmanın olduğu, derse ilişkin iki tezin $\left(T_{1}, T_{3}\right)$ ve iki makalenin $\left(M_{5}, M_{7}\right)$ yayınlandığı görülmektedir. Matematik dersi kapsamında geliştirilen tezlerinin ikisi de 2015 yılına aitken, 2015 yılına ait bir tez Din Kültürü ve Ahlak Bilgisi dersine aittir. Makalelerin biri 2018 yılında, diğeri ise 2020 yılında yayınlanmıştır. Matematik dersinden sonra disiplin alanı olarak daha sık tercih edilen dersin Türkçe olduğu, Türkçe dersine ilişkin bir tezin $\left(T_{7}\right)$ ve iki makalenin $\left(M_{1}, M_{2}\right)$ yayınlandığı, geliştirilen tezin 2019 yılına ait, makalelerin ise 2015 yılına ait olduğu görülmektedir. Fen bilimleri dersine ilişkin iki tezin $\left(T_{5}, T_{8}\right)$ olduğu görülmektedir. Fen bilimleri dersi kapsamında geliştirilen tezlerinin bir tanesi 2017 yılına, diğeri 2019 yılına aittir. Hayat bilgisi dersine ilişkin bir tez $\left(T_{10}\right)$ geliştirildiği, bir makale $\left(\mathrm{M}_{3}\right)$ yayınlandığı görülmektedir. Hayat bilgisi dersi kapsamında geliştirilen tez 
2020 yılına aitken, makale ise 2015 yılına aittir. Müzik dersine ilişkin bir tezin $\left(T_{2}\right)$ geliştirildiği, bir makalenin $\left(M_{6}\right)$ yayınlandığı görülmektedir. Müzik dersi kapsamında geliştirilen tez 2015, makale ise 2019 yılına aittir. Sosyal bilgiler dersi kapsamında 2018 yılına ait bir tez $\left(T_{6}\right), 2019$ yılında yayınlanan bir makale $\left(\mathrm{M}_{5}\right)$ işbirlikli öğrenme yaklaşımının metaforik algıların belirlenmesini konu alırken, 2019 yılında geliştirilen bir tez $\left(T_{9}\right)$ yaratıcı yazma becerilerini konu almaktadır. Son olarak 2020 yılında yayınlanan bir makalede $\left(\mathrm{M}_{8}\right)$ "Bütünleşme Ölçeğinin Geliştirilmesi" konulu bir çalışma yapıldığı görülmektedir.

Tablo 3.

Çalışmaya dahil edilen makale ve tezlerin eğitim kademesine göre dağııımı

\begin{tabular}{lrr}
\hline Kademe & Kod & $f$ \\
\hline 1. Sinıf & - & 0 \\
2. Sinıf & $T_{3}, T_{7}$ & 2 \\
3. Sinıf & $M_{3}, T_{10}$ & 2 \\
4. Sinıf & $M_{1}, M_{2}, M_{4}, M_{5}, M_{6}, M_{7}, M_{8}, T_{1}, T_{2}, T_{4}, T_{5}, T_{6}, T_{8}, T_{9}$ & 14 \\
\hline
\end{tabular}

Makale ve tezlerin eğitim kademesine göre dağılımının yoğun olarak 4. sınıf düzeyinde yoğunlaştığı göze çarpmaktadır. Çalışmaların yedi makale $\left(M_{1}, M_{2}, M_{4}, M_{5}, M_{6}, M_{7}, M_{8}\right)$, yedi tez $\left(T_{1}\right.$, $T_{2}, T_{4}, T_{5}, T_{6}, T_{8}, T_{9}$ ) olmak üzere toplam on dört akademik yayında ilkokul 4. sınıf kademesindeki öğrencilerle çalışma yürütülmüştür. Biri makale $\left(\mathrm{M}_{3}\right)$, biri tez $\left(\mathrm{T}_{10}\right)$ olmak üzere toplam iki yayında ilkokul 3. sınıf kademesindeki öğrencilerle çalışılırken, iki tezde $\left(T_{3}, T_{7}\right)$ ilkokul 2. sınıf kademesindeki öğrencilerle çalışımıştır. Birinci sınıf düzeyinde 2015-2021 yılları arasında bir çalışmaya rastlanmamıştır.

Tablo 4.

Çalışmaya dâhil edilen makale ve tezlerin amaçlarına ilişkin bulgular

\begin{tabular}{|c|c|c|c|}
\hline Temalar & $\begin{array}{l}\text { Kategori } \\
\text { (İşbirlikli Öğretim Yaklaşımı) }\end{array}$ & Kod & $f$ \\
\hline \multirow[t]{7}{*}{ Beceri, Erişi ve Kalıcılık } & Okuduğunu anlama & $M_{1}$ & \\
\hline & Yansıtıcı düşünme & $\mathrm{M}_{3}$ & \\
\hline & Problem çözme & $\mathrm{M}_{4}$ & \\
\hline & Şarkı söyleme & $M_{6}$ & \\
\hline & Ritim becerisi ve öz yeterlik algısı & $\mathrm{T}_{2}$ & 8 \\
\hline & Erişiye, kalıcılığa ve sosyal beceriye & $T_{3}$ & \\
\hline & Sosyal becerilere ve akran zorbalığı & $T_{6}$ & \\
\hline \multirow[t]{2}{*}{ Akademik Başarı } & Yaratıcı yazma ve sosyal duygusal öğrenme & $\mathrm{T}_{9}$ & \\
\hline & Akademik başarı & $M_{2}, M_{7}, T_{4}$ & 6 \\
\hline \multirow[t]{4}{*}{ Tutum } & Kalıcılık ve üst bilişsel farkındalık & $\mathrm{T}_{1}, \mathrm{~T}_{5}, \mathrm{~T}_{8}$ & \\
\hline & Matematiğe dersine yönelik & $M_{7}$ & \\
\hline & Türkçe dersine yönelik & $\mathrm{T}_{7}$ & 3 \\
\hline & Empatik eğilim ve hayat bilgisi dersine yönelik & $\mathrm{T}_{10}$ & \\
\hline Metafor & İşbirliği kavramına yönelik metaforik algı & $\mathrm{M}_{5}$ & 1 \\
\hline Ölçek & Bütünleşme üzerine ölçek geliştirme & $M_{8}$ & 1 \\
\hline
\end{tabular}

İşbirlikli öğrenme-öğretme yaklaşımına yönelik geliştirilen makale ve tezlerde en fazla tercih edilen amacın beceri, erişi ve kalıcılık odaklı çalışmalar olduğu görülmektedir. Makale ve tezlerde en fazla tercih edilen bir diğer amacın akademik başarı üzerine olduğu bulgusuna ulaşılmıştır. Tablo 5 incelendiğinde; dört makale $\left(M_{1}, M_{3}, M_{4}, M_{6}\right)$ ve dört tezde $\left(T_{2}, T_{3}, T_{6}, T_{9}\right)$ işbirlikli öğrenme yaklaşımıyla "Beceri, Erişi ve Kalıcılık" temasında "Okuduğunu anlama, Yansıtıcı düşünme, Problem 
çözme, Şarkı söyleme, Ritim, Erişi, Kalıcılık, Yaratıcı yazma" değişkenlerine etkisinin ortaya çıkarılması amaçlanmaktadır. Ayrıca üç tezde $\left(T_{3}, T_{6}, T_{9}\right)$ "Sosyal Beceriler" üzerindeki etkinin ortaya çıkarılması amaçlanmıştır. Çalışmaya dâhil edilen iki makale, $\left(M_{2}, M_{7}\right)$ ve dört tezde $\left(T_{1}, T_{4}, T_{5}, T_{8}\right)$ işbirlikli öğrenme yaklaşımıyla "Akademik başarı" temasında "Dil Bilgisi, Doğal Sayılar ve İşlemler, Ölçme, Madde ve Doğası" öğrenme alanlarında etkisinin ortaya çıkarılması amaçlanmıştır. Çalışmaya dâhil edilen bir makalede $\left(M_{7}\right)$ ve iki tezde $\left(T_{7}, T_{10}\right)$ çalışmaların işbirlikli öğrenme yaklaşımıyla "Tutum" temasında "Matematik, Türkçe, Hayat Bilgisi" derslerine yönelik etkinin ortaya çıkarılması amaçlanırken, sadece bir makalede $\left(M_{5}\right)$ işbirliği kavramına yönelik metaforları incelenmiş, bir makalede $\left(M_{8}\right)$ bütünleşme ölçeğinin geliştirilmesi amaçlanmıştır.

Tablo 5.

Çalışmaya dâhil edilen makale ve tezlerin işbirlikli öğrenme tekniklerine ilişkin bulgular

\begin{tabular}{lrr}
\hline Teknik & & Kod \\
(Işbirlikli Öğretim Yaklaşımı) & $f$ \\
\hline Jigsaw & $\mathrm{T}_{4,} \mathrm{~T}_{5}, \mathrm{~T}_{6}, \mathrm{~T}_{8}, \mathrm{~T}_{10}$ & 5 \\
Takım Oyun Turnuva Tekniği & $\mathrm{M}_{2}, \mathrm{M}_{7}, \mathrm{~T}_{3}$ & 3 \\
Birlikte öğrenme tekniği & $\mathrm{M}_{3}, \mathrm{M}_{6}, \mathrm{~T}_{2}$ & 3 \\
Öğrenci Takımları Başarı Bölümleri Tekniği & $\mathrm{T}_{3}, \mathrm{~T}_{7}$ & 2 \\
Tartışma Sorgulama Tekniği & $\mathrm{M}_{1}$ & 1 \\
Improve tekniği & $\mathrm{M}_{4}$ & 1 \\
İkili denetim tekniği & $\mathrm{T}_{1}$ & 1 \\
Takım Destekli Bireyselleştirme Tekniği & $\mathrm{T}_{3}$ \\
İşbirlikli Dijital Hikaye Hazırlama & 1 \\
- & $\mathrm{T}_{9}$ & 1 \\
- & $\mathrm{M}_{5}$ & 1 \\
\hline
\end{tabular}

İşbirlikli öğrenme-öğretme yaklaşımıyla tasarlanmış makale ve tezler incelendiğinde; beş tezde $\left(T_{4}, T_{5}, T_{6}, T_{8}, T_{10}\right)$ amaçlarına paralel olarak "Jigsaw tekniği" ile "Beceri", "Akademik başarı", "Kalıcılık" ve "Tutum" temalarında çalışmalar yürütülmüştür. Araştırmacıların makale ve tezlerinde sıklıkla bu tekniği kullandığı görülmektedir. Araştırmaya dâhil edilen üç makalede $\left(M_{2}, M_{7}, T_{3}\right)$ amaçlarına yönelik "Takım Oyun Turnuva Tekniği" kullanılarak "Akademik başarı", "Tutum, "Beceri" ve "Kalıcılık" temalarında çalışmalar yürütülmüştür. Yine iki makalede $\left(M_{3}, M_{6}\right)$ bir tezde $\left(T_{2}\right)$ amaçları doğrultusunda "Birlikte öğrenme tekniği" kullanarak "Akademik Başarı" ve "Beceri" temasında çalışmalar yürütülmüş̧ür. İki tezde $\left(T_{3}, T_{7}\right)$ amacına uygun olarak "Öğrenci Takımları Başarı Bölümleri Tekniği" kullanarak "Beceri" ve "Tutum" temasında çalışmalar gerçekleştirilmiş, bir makalede $\left(\mathrm{M}_{1}\right)$, "Tartışma Sorgulama Tekniği" kullanarak "Beceri" temasında çalışma gerçekleştirilmiştir. Sadece bir makalede amacına ilişkin $\left(\mathrm{M}_{4}\right)$ "Improve tekniği" kullanarak "Beceri" temasında çalışma gerçekleştirilmiştir. Son olarak bir tezde $\left(T_{1}\right)$ "Akademik başarı" temasında "ikili denetim tekniği", bir tez $\left(T_{3}\right)$ "Beceri" temasında "Takım Destekli Bireyselleştirme Tekniği" bir tezde $\left(T_{9}\right)$ "Beceri" temasında "İ̧̧birlikli Dijital Hikâye Hazırlama Tekniği" kullanılarak amaçlarına uygun çalışma yürütülmüştür. İki makalede $\left(\mathrm{M}_{5}, \mathrm{M}_{8}\right)$ kullanılan teknik belirtilmemiştir.

Tablo 6.

Çalışmaya dâhil edilen makale ve tezlerin sonuçlarına ilişkin bulgular

\begin{tabular}{llll} 
Temalar & Kategori & $\begin{array}{l}\text { Alt Kategori } \\
\text { (İş̧irlikli Öğretim Yaklaşımı) }\end{array}$ & Kod \\
\hline
\end{tabular}




\begin{tabular}{|c|c|c|c|c|}
\hline \multirow{7}{*}{$\begin{array}{l}\text { Beceri, Erişi ve } \\
\text { Kalıcılık }\end{array}$} & \multirow{6}{*}{ Olumlu } & \multirow{5}{*}{$\begin{array}{l}\text { Okuduğunu anlama } \\
\text { Yansıtıcı düşünme } \\
\text { Problem çözme } \\
\text { Şarkı söyleme } \\
\text { Ritim }\end{array}$} & \multicolumn{2}{|l|}{$\mathrm{M}_{1}$} \\
\hline & & & \multirow{2}{*}{\multicolumn{2}{|c|}{$\begin{array}{l}M_{3} \\
M_{4} 8\end{array}$}} \\
\hline & & & & \\
\hline & & & $M_{6}$ & \\
\hline & & & $\mathrm{T}_{2}$ & \\
\hline & & Erişi, kalıcılık ve sosyal & $T_{3}, T_{4}, T_{6}$ & \\
\hline & Nötr & Sosyal duygusal öğrenme & $\mathrm{T}_{9}$ & 1 \\
\hline \multirow{3}{*}{ Akademik Başarı } & \multirow{3}{*}{ Olumlu } & Başarı Düzeyini Artırma & $M_{2}, M_{7}$ & \\
\hline & & Üst bilişsel farkındalık & $\mathrm{T}_{1}$ & 5 \\
\hline & & Kalıcılık & $T_{5}, T_{8}$ & \\
\hline \multirow{3}{*}{ Tutum } & \multirow{3}{*}{ Olumlu } & Matematik & $M_{7}$ & \\
\hline & & Türkçe & $\mathrm{T}_{7}$ & 3 \\
\hline & & Hayat bilgisi & $\mathrm{T}_{10}$ & \\
\hline Metafor & Olumlu & İşbirliği kavramı & $\mathrm{M}_{5}$ & 1 \\
\hline Ölçek & Olumlu & Bütünleşme düzeyi & $\mathrm{M}_{8}$ & 1 \\
\hline
\end{tabular}

Iş̧birlikli öğrenme yaklaşımıyla tasarlanan makale ve tezlerin hepsinin "Beceri, Erişi ve Kalıcılık" temasında amaçladığı "Okuduğunu anlama, Yansıtıcı düşünme, Problem çözme, Şarkı söyleme, Ritim, Erişi, Kalıcılık, Yaratıcı yazma" değişkenleri üzerinde etkisinin çalışma grubu lehine anlamlı yönde farklılaştığı sonucuna ulaşmıştır. Makale ve tezlerde beceri, erişi ve kalıcılık temasında yoğun olarak olumlu sonuçların elde edildiği ortaya çıkmıştır. Nitekim üç tezde $\left(T_{3}, T_{4}, T_{6}\right)$ "Sosyal beceriler" alt kategorisinde çalışma grubunun lehine anlamlı yönde farklılaştığı sonucuna ulaşımıştır. Ancak bir tezde $\left(T_{9}\right)$, işbirlikli öğrenme yaklaşımıyla hazırlanan ders içeriğinin öğrencilerin "Sosyal duygusal öğrenme becerileri" üzerinde etkisi olmadığı sonucuna ulaşıımıştır. Çalışmaya dâhil edilen iki makalede $\left(M_{2}, M_{7}\right)$ ve üç tezde $\left(T_{1}, T_{5}, T_{8}\right)$ işbirlikli öğrenme yaklaşımıyla "Akademik başarı" temasında amaçladığı "Dil Bilgisi, Doğal Sayılar ve işslemler, Ölçme, Madde ve Doğası" öğrenme alanlarında etkisinin çalışma grubu lehine anlamlı yönde farklılaştığı sonucuna ulaşılış̧tır. Bir makalede $\left(M_{7}\right)$ ve iki tezde $\left(T_{7}, T_{10}\right)$ işbirlikli öğrenme yaklaşımıyla "Tutum" temasında "Matematik, Türkçe, Hayat bilgisi" derslerine yönelik değişkenleri üzerinde olumlu katkı sağladığı sonucuna ulaşıımıştır. Bir makalede $\left(M_{5}\right)$ işbirliği kavramına yönelik olumlu metaforlar üretildiği sonucuna ulaşılırken, bir makalede $\left(\mathrm{M}_{8}\right)$ işbirlikli öğrenme yaklaşımına ilişkin bütünleşme ölçeğinden alınan puan yükseldikçe, öğrencinin daha yüksek bütünleşme düzeyine sahip olduğu sonucuna ulaşılmıştır.

Tablo 7.

Çalışmaya dâhil edilen makale ve tezlerin önerilerine ilişkin bulgular

\begin{tabular}{|c|c|c|c|}
\hline Temalar & $\begin{array}{l}\text { Kategoriler } \\
\text { (İşbirlikli Öğretim Yaklaşımı) }\end{array}$ & Kod & $f$ \\
\hline & Çeşitli öğretim kademelerinde ve farklı derslerde & $M_{1}, M_{3}, M_{4}, T_{2}, T_{10}$ & \\
\hline \multirow[t]{2}{*}{ Uygulama } & Öğretmenlerin günlük planlarında & $M_{5}, T_{6}$ & 7 \\
\hline & Uygulama biçimine yönelik & $M_{2}, M_{7}, T_{8}$ & \\
\hline \multirow{2}{*}{$\begin{array}{l}\text { Hizmet İçi } \\
\text { Eğitim }\end{array}$} & Müzik eğitimine yönelik & $M_{6}$ & 9 \\
\hline & Akademik, sosyal etkilerine yönelik & $T_{1}, T_{3}, T_{4}, T_{5}, T_{7}$ & \\
\hline & Geleceğe yönelik farklı araştırmalar yapılması & $M_{1}, M_{2}, M_{3}, M_{4}, M_{5}, M_{6}, M_{7}$ & \\
\hline Araştırmacılara & İlkokulun farklı kademelerinde ölçek çalışması & $T_{1}, T_{2}, T_{3}, T_{5}, T_{7}, T_{8}, T_{10}$ & 17 \\
\hline Yönelik & Dijital hikaye anlatımına yönelik benzer çalışmalar & $M_{8}, T_{9}$ & \\
\hline
\end{tabular}


Araştırmacıların makale ve tezlerinde en fazla öneride bulundukları konunun ilkokul düzeyinde işbirlikli öğrenme-öğretme yaklaşımına yönelik farklı araştırmaların yapılmasıdır. Tablo 8 incelendiğinde; araştırmaya dâhil edilen dört makalede $\left(M_{1}, M_{3}, M_{4}, M_{5}\right)$, üç tezde $\left(T_{2}, T_{6}, T_{10}\right)$ "Uygulama" temasında işbirlikli öğrenme yaklaşımının farklı sınıf seviyelerinde, farklı tekniklerle ve farklı derslerde uygulanabileceği önerilmektedir. Üç makalede $\left(M_{2}, M_{6}, M_{7}\right)$, altı tezde $\left(T_{1}, T_{3}, T_{5}, T_{7}, T_{8}\right)$ ise "Hizmet İçi Eğitim" temasında diğer öğretim teknikleriyle ilgili, yaklaşımın yararlarının ve uygulama biçiminin kazandırılmasına yönelik önerilerde bulunulmaktadır. Son olarak "Araştırmacılara Yönelik" temasında yedi makalede $\left(M_{1}, M_{2}, M_{3}, M_{4}, M_{5}, M_{6}, M_{7}\right)$, sekiz tezde $\left(T_{1}, T_{2}, T_{3}, T_{5}, T_{7}, T_{8} T_{10}\right)$ ve bir makalede $\left(\mathrm{M}_{8}\right)$, bir tezde $\left(\mathrm{T}_{9}\right)$ geleceğe yönelik farklı araştırmaların yapılabileceği, ilkokulun farklı kademelerinde geçerlik-güvenirlik çalışmalarının yapılabileceği ve farklı çalışmalara rehber niteliği olarak araştırmanın kullanılabileceğini önerilmektedir.

\section{Tartışma, Sonuç ve Öneriler}

Araştırmaya dâhil edilen makale ve tezler yıllara göre değerlendirildiğinde, ilkokulda işbirlikli öğrenme yaklaşımıyla en çok 2015 ve 2019 yıllarında yayın yapıldığı, 2015 yılından sonra yayın sayısında düşüş gözlenirken 2017 yılından sonra ise tekrar bir artış olduğu görülmektedir. Bu artışın nedeni çağdaş eğitim anlayışıla paralel olarak ülkemizde işbirlikli öğrenme ve öğretme yaklaşımına uygun hazırlanan eğitim ortamlarının öğrenenlere; aktif öğrenme, güç birliği içinde öğrenme, zengin konu içeriği, gruplar halinde çalışma vb. gibi birçok açıdan fırsat sunmasıyla açıklanabilir. Ayrıca ilkokul düzeyinde çalışılan makale ve tezlerin en fazla 4. sınıf kademesinde gerçekleştirildiği, 1 . sınıf düzeyinde 2015-2021 yılları arasında işbirlikli öğrenme-öğretme yaklaşımıyla tasarlanmış bir yayın olmadığı görülmektedir. Benzer şekilde Taş ve Akoğlu (2020) ülkelere göre işbirlikli öğrenme ve öğretme yaklaşımıyla yapılan çalışmaları karşılaştırdığında çalışmaların yarısından fazlasının Türkiye'de yapıldığını, ilkokul düzeyinde yapılan çalışmalarında 4. sınıf düzeyinde tasarlandığını ifade etmiştir.

Makale ve tezler disiplin alanlarına göre değerlendirildiğinde en fazla çalışılan disiplin alanının "Matematik" dersi olduğu görülmektedir. Bilindiği üzere matematik dersi; açıklama, düzenleme, örüntü arama, kıyaslama, sınıflama, uygulama, sonuç çıkarma, modelleme, soyutlama, ikna etme, genelleme, analize ve senteze varma gibi bir dizi beceri gerektirir (Boz, 2018; Kutluk, 2011; Olkun ve Toluk, 2012; Yaman ve Umay, 2013). Matematik dersinin çok aşamalı işlemler gerektirmesi, zorlu bir öğrenme sürecinin olması (Konukoğlu, 2019; Mumcu, 2018) göz önüne alındığında araştırmacılar bu zorlukları giderme ve kalıcı öğrenmeleri gerçekleştirmenin bir yolu olarak işbirlikli öğrenme-öğretme yaklaşımıyla araştırmalarını tasarlamış olabilir. Ancak işbirlikli öğrenme-öğretme yaklaşımı öğrenmeyi en üst seviyede gerçekleştirme amacı taşıyan (Yılmaz, 2007), farklı öğrenme stillerine ve farklı disiplin alanlarına hitap eden bir yaklaşımdır (ileri, Selvi ve Köse, 2020; Johnson, Johnson ve Smith, 2014; Kardaş ve Cemal, 2015; Oktan ve Budak, 2021; Önder ve Sılay, 2015). Bu açıdan bakıldığında farklı derslerde de kullanılması gereken bir öğrenme- öğretme yaklaşımıdır.

İşbirlikli öğrenme-öğretme yaklaşımıyla tasarlanmış makale ve tezler incelendiğinde; en fazla

"Jigsaw Tekniği" ile tasarlandığı, "Beceri", "Akademik başarı", "Kalıcılık" ve "Tutum" temalarına yönelik deneysel çalışmaların yürütüldüğü tespit edilmiştir. Jigsaw tekniği uygulanma biçimi gereği heterojen takımların oluşturulması, öğrencilere bir konu hakkında uzmanlaşma fırsatının tanınması, 
grup üyesinin her birinin uzmanı olduğu konunun öğrenilmesinden sorumlu olması ve kendi takımlarına dönerek öğrendikleri konuyu diğerlerine öğretme sorumluluğunun olması (Kocabaş, 2016) ilkeleriyle zengin bir portföy oluşturması araştırmacılar için seçim nedeni olarak değerlendirilebilir.

Çalışmalar amaçlarına göre incelendiğinde "Beceri, Erişi ve Kalıcılık", "Akademik Başarı" ve "Tutum" ve "Diğer" olmak üzere dört temaya ulaşılmıştır. İşbirlikli öğrenme-öğretme yaklaşımının "Beceri, Erişi ve Kalıcılık" temasında "Okuduğunu anlama, Yansıtıcı düşünme, Problem çözme, Şarkı söyleme, Ritim Tutma, Erişi, Kalııııı, Yaratıcı yazma” becerilerinin kazandırılması, erişiye ve kalıcılığa etkisi gibi çalışmaların daha fazla alanyazında yer aldığı sonucuna ulaşılmış, bulgular, sonuçlar ve öneriler değişkenlerine göre de bir yayın hariç bütün makale ve tezlerin çalışmasında bu yaklaşımın belirlenen becerilerin kazandırılmasında olumlu katkı sağladığı sonucuna ulaşımıştır. İşbirlikli öğrenme-öğretme yaklaşımının temel hedefleri irdelendiğinde; öğrenenlere akademik olarak belirlenen konunun kazandırılması sürecinde kişisel, kişilerarası ve sosyal becerilerin öğretilmesi, grubun bir ekip ruhu ile çalışmasını eş zamanlı olarak teşvik edilmesi prensiplerine sahip olmasıyla açıklamak mümkündür (Deniz, 2020; Kocabaş, 2016; Saban, 2014). Ayrıca farklı sınıf seviyelerinde, farklı tekniklerle ve farklı derslerde uygulanabilmesinin araştırmacılar tarafından daha sık önerildiği sonucuna ulaşılmıştır.

Bu araştırmada ilkokulda işbirlikli öğrenme-öğretme yaklaşımıyla tasarlanmış makale ve tez içerikleri analiz edilmeye çalışılmış ve her bir makale ve tez yorumlanmaya çalışıımıştır. Araştırmaya dâhil edilen tüm makale ve tezlerin ulusal alanyazındaki çalışmalar ile uyum içerisinde olduğu, benzer araştırmalar yapan Taş ve Akoğlu (2020)'nun gerçekleştirdiği meta-sentez çalışmasına yönelik bulguları ile desteklenmiştir. Araştırmada incelenen makale ve tezlere derinlemesine bakıldığında; işbirlikli öğrenme-öğretme yaklaşımıyla tasarlanmış derslerin öğrenenler üzerinde akademik başarı, motivasyon, tutum, özyeterlik gibi temel yeterlik ve becerilere olumlu yönde katkı sağladığı ortak vurgu olarak ortaya çıkarılmıştır. İşbirlikli öğrenme-öğretme yaklaşımının duyuşsal becerilere etkisine yönelik yapılan çalışmalar da bu durumu desteklemektedir (Genç ve Şahin, 2015; Öztürk ve Kalyoncu, 2018; Tuğral ve Güvenç, 2016; Yıldız, Ağgül, Çalıklar ve Şimşek, 2021). Bu kapsamda;

- Araştırmada görüldüğü gibi daha çok beceri alanları akademik başarı geliştirme üzerine yoğunlaşmış, sosyal ya da duyuşsal becerilerin geliştirilmesinde ise çalışmalarda daha az yer verildiği sonucuna ulaşıımıştır. Bu doğrultuda ilkokul düzeyinde işbirlikli öğrenme yaklaşımının öğrencilerin sosyal ve duyuşsal becerilerini geliştirmeye yönelik çalışmaların yapılması önerilebilir.

- Makale ve tezlerde araştırmacıların çalışma grubu olarak dördüncü sınıf düzeyine yoğunlaştığı sonucuna ulaşılmıştır. illkokul birinci sınıf düzeyinde öğrenim gören öğrencilere yönelik işbirlikli öğrenme-öğretme yaklaşımıyla tasarlanmış deneysel çalışmaların uygulanması önerilebilir.

- İşbirlikli öğrenme-öğretme yaklaşımıyla yoğun olarak deneysel çalışmaların yürütüldüğü sonucuna ulaşıımıştır. Ancak alanyazında işbirlikli öğrenme-öğretme yaklaşımıyla tasarlanmış boylamsal çalışmaların kısıtlı olduğu görülmektedir. İşbirlikli öğrenme-öğretme yaklaşımının öğrenme, sosyal beceri geliştirme gibi alanlar üzerindeki uzun soluklu etkilerinin ortaya çıkarılmasına yönelik çalışmaların yapılması önerilebilir.

- Araştırmacılara, daha geniş yıllar arasında, farklı veritabanları da taranarak ve yabancı kaynaklarında dâhil edilebileceği derleme çalışmalarının yapııması önerilebilir. 


\section{Kaynakça}

Açıkgöz, K. Ü. ve Güngör, A. (2006). İşbirlikli öğrenme yönteminin okuduğunu anlama stratejilerinin kullanımı ve okumaya yönelik tutum üzerindeki etkileri. Kuram ve Uygulamada Eğitim Yönetimi, 48(48), 481-502. https://dergipark.org.tr/en/pub/kuey/issue/10349/126748

Aktan, O. ve Budak, Y. (2021). Matematik dersinde takım destekli bireyselleştirme tekniğinin kullanılmasına yönelik veli görüşlerinin incelenmesi1. Kalem Eğitim ve Insan Bilimleri Dergisi 2021, 11(2), 391-417, https://10.23863/kalem.2021.179

Arısoy, B. ve Tarim, K. (2013). İşbirlikli öğrenme yönteminin öğrencilerin akademik başarı, kalıcılık ve sosyal beceri düzeylerine etkisi. Hacettepe Üniversitesi Eğitim Fakültesi Dergisi,28(28-3), 1-14. https://dergipark.org.tr/en/pub/hunefd/issue/7791/101936

Aslan, A. (2018). Sistematik derleme ve meta-analizi. Acta Medica Alanya, 2(2), 62-63. https://doi.org/10.30565/medalanya.439541

Bakioğlu, A. ve Göktaş, E. (2020). Ortaokul Matematik ve Fen Bilimleri Derslerinde İşbirlikli Öğrenmenin Başarıya Etkisi: Bir Meta-Analiz Çalışması. Harran Maarif Dergisi, 5(1), 1-30. http://dx.doi.org/10.22596/2020.0501.1.30

Batdı, V. (2014). jigsaw tekniğinin öğrencilerin akademik başarılarına etkisinin meta-analiz yöntemiyle incelenmesi. EKEV Akademi Dergisi, 58(58), 699-714.

Bayrakçeken, S., Doymuş, K. ve Doğan, A. (2013). Işbirlikli öğrenme modeli ve uygulanması. Ankara: Pegem akademi.

Bilgin, i. ve Gelici, Ö. (2011). İşbirlikli öğrenme tekniklerinin tanıtımı ve öğrenci görüşlerinin incelenmesi. Adıyaman Üniversitesi Eğitim Bilimleri Dergisi, 1(1), 40-70. https://dergipark.org.tr/en/pub/adyuebd/issue/1372/16169

Carlos Torrego-Seijo, J., Caballero-García, P. Á. ve Lorenzo-Llamas, E. M. (2021). The effects of cooperative learning on trait emotional intelligence and academic achievement of Spanish primary school students. British Journal of Educational Psychology, 91(3), $928-949$. https://doi.org/10.1111/bjep.12400

Cartwright, S. (1993). Cooperative learning can occur in any kind of program. Young Children, 48(2), 12-14. http://www.jstor.org/stable/42726421

Cohen, S. ve Willis, T. (1985). Stress and social support and the buffering hypothesis. Psychological Bulletin. 98(2), 310-357. https://doi.org/10.1037/0033-2909.98.2.310

Çubukçu, Z. (2020). Iş̧birlikli öğrenme. B. Oral (Ed). Öğrenme öğretme kuram ve yaklaşımları içinde (467-663). Pegem Yayıncılık.

Demirtaş, Z. (2010). Okul kültürü ile öğrenci başarısı arasındaki ilişki. Eğitim ve Bilim, 35(158), 3-13.

Dendup, T. ve Onthanee, A. (2020). Effectiveness of Cooperative Learning on English Communicative Ability of 4th Grade Students in Bhutan. International Journal of Instruction, 13(1), 255-266.

Deniz, J. Gagne'nin Öğretim Kuramı Temelinde Yapılandırılmış Piyano Derslerinde İşbirlikli Öğrenme Yönteminin İşlevselliği. OPUS Uluslararası Toplum Araştırmaları Dergisi, 16(31), 4097-4137. https://10.26466/opus.680488

Dirik, M.Z. (2015). Öğretim ilke ve yöntemleri. Pegem Akademi.

Doymuş, K., Şimşek, Ü. ve Şimşek, U. (2005). İşbirlikçi öğrenme yöntemi üzerine derleme: ı. işbirlikçi öğrenme yöntemi ve yöntemle ilgili çalışmalar. Erzincan Üniversitesi Eğitim Fakültesi Dergisi, 7(1), 59-83.

Driscoll, M. P. (2012). Öğretim süreçleri ve öğrenme psikolojisi. Anı Yayıncılık.

Doğan, A., Doymuş, K., Gök, Ö. ve Karaçöp, A.(2009). İşbirlikli Öğrenme yönteminin ilköğretim öğrencilerinin akademik başarılarına ve fene olan tutumlarına etkileri. Gazi Eğitim Fakültesi Dergisi. 29(1), 193-209.

Erbil, D. G. ve Kocabaş, A. (2019). Sınıf öğretmenlerinin eğitimde teknoloji kullanımı, tersine çevrilmiş sınıf ve işbirlikli öğrenme hakkındaki görüşleri. ilkogretim Online, 18(1). 31-51. https://10.17051/ilkonline.2019.527150

Fernandez-Rio, J., Sanz, N., Fernandez-Cando, J. ve Santos, L. (2017). Impact of a sustained Cooperative Learning intervention on student motivation. Physical Education and Sport Pedagogy, 22(1), 89-105. https://doi.org/10.1080/17408989.2015.1123238

Garrison, D. R. ve Cleveland-Innes, M. (2005). Facilitating cognitive presence in online learning: Interaction is not enough. The American journal of distance education, 19(3), 133-148. https://doi.org/10.1207/s15389286ajde1903_2 
Genç. M. ve Şahin, F. (2015). İşbirlikli öğrenmenin başarıya ve tutuma etkisi. Necatibey Eğitim Fakültesi Elektronik Fen ve Matematik Eğitimi Dergisi, 9(1), 375-396. https://10.17522/nefefmed.2127

Goodwin, M. W. (1999). Cooperative learning and social skills: What skills to teach and how to teach them. Intervention in school and clinic, 35(1), 29-33. https://doi.org/10.1177/105345129903500105

Gut, D. M. ve Safran, S. P. (2002). Cooperative learning and social stories: Effective social skills strategies for reading teachers. Reading ve Writing Quarterly, 18(1), https://doi.org/10.1080/105735602753386351

Higgins, J. P., Thomas, J., Chandler, J., Cumpston, M., Li, T. (2019). Cochrane handbook for systematic reviews of interventions. Page, M. J. ve Welch, V. A. (Eds.). John Wiley ve Sons.

Hortigüela Alcalá, D., Hernando Garijo, A., Perez-Pueyo, A. ve Fernandez-Rio, J. (2019). Cooperative learning and students' Motivation, social interactions and attitudes: perspectives from two different educational stages. Sustainability, 11(24), 7005.

İleri, Y. E., Selvi, M. ve Köse, M. (2020). Fen bilimleri eğitiminde işbirlikli öğrenme yaklaşımının akademik başarıya etkisi: bir meta-analiz çalışması. Ihlara Eğitim Araştırmaları Dergisi, 5(1), 51-84. http://ihead.aksaray.edu.tr/en/pub/issue/51451/67932

Johnson D. W. ve Johnson R. T. (1999). Making cooperative learning work. Theory into Practice, 38(2), 67-73. https://doi.org/10.1080/00405849909543834

Johnson, D. W. ve Johnson, R. T. (2009). An educational psychology success story: social interdependence theory and cooperative learning. Educational Researcher, 38(5), 365- 379. https://doi.org/10.3102/0013189X09339057

Johnson, D. W., Johnson, R. T. ve Holubec, E. J. (1991). Cooperation in the classroom. Interaction Book Company.

Johnson, D. W.,Johnson, R. T. ve Holubec J. E. (2016). Işsirlikli öğrenme el kitabı(1. baskı.) Kocabaş, A. (Ed). Ankara: Pegem Akademi Yayıncılık.

Johnson, D. W., Johnson, R. T. ve Smith, K. A. (1991). Cooperative Learning: Increasing College Faculty Instructional Productivity. ASHE-ERIC Higher Education Report No. 4, 1991. ASHE-ERIC Higher Education Reports, George Washington University, One Dupont Circle, Suite 630, Washington, DC 20036-1183.

Johnson, D. W., Johnson, R. T. ve Smith, K. A. (2014). Cooperative learning: Improving university instruction by basing practice on validated theory. Journal on Excellence in University Teaching, 25(4), 1-26.

Johnson, D. W., Johnson, R. T., ve Taylor, B. (1993). Impact of cooperative and individualistic learning on highability students' achievement, self-esteem, and social acceptance. The Journal of Social Psychology, 133(6), 839-844. https://doi.org/10.1080/00224545.1993.9713946

Joyce, B., Weil, M. ve Calhoun, E. (2009). Models of Teaching (8th edition.). Pearson Education.

Kagan, S. (1986). Cooperative learning and sociocultural factors in schooling. Beyond language: Social and cultural factors in schooling language minority students, 231, 298.

Kara, C. O. (2016). Flipped classroom. Tıp Eğitimi Dünyası, 15(45), 12-26. https://doi.org/10.25282/ted.256096

Karaçam, Z. (2013). Sistematik derleme metodolojisi: sistematik derleme hazırlamak için bir rehber. Dokuz Eylül Üniversitesi Hemşirelik Yüksekokulu Elektronik Dergisi, 6(1), 26-33.

Karalı, Y. ve Aydemir, H. (2020). İşbirliğine dayalı öğrenme yönteminin ilkokul matematik dersine ve matematiğe karşı tutuma etkisi1. Journal of History School (JOHS), 13(47) http://dx.doi.org/10.29228/Joh.41432

Kardaş, M. ve Cemal, S. (2015). İşbirlikli öğrenme tekniklerinin türkçe öğretiminde başarı, tutum ve uygulamalara yönelik öğrenci görüşleriyle ilişkisi. Mustafa Kemal Üniversitesi Sosyal Bilimler Enstitüsü Dergisi, 12(30), 231-250. https://dergipark.org.tr/en/pub/mkusbed/issue/19576/208889

Kartal, Ş. ve Özbek, R. (2017). İşbirlikli öğrenme yönteminin öğrencilerin ingilizce dersine yönelik tutumlarina ve başarilarina etkileri. Abant Izzet Baysal Üniversitesi Eğitim Fakültesi Dergisi, 17(2), 796-820. https://doi.org/10.17240/aibuefd.2017.17.30227-326598

Kocabaş, A. (2016). İşbirlikli öğrenme el kitabı. Pegem Akademi.

Kocak, R. (2008). The effects of cooperative learning on psychological and social traits among undergraduate students. Social Behavior and Personality: an international journal, 36(6), 771782.https://doi.org/10.2224/sbp.2008.36.6.771

Konukoğlu, L., Ağaç G. ve Özmantar, M. F. (2019). Cumhuriyet dönemi ilkokul matematik dersi öğretim programlarının matematik okuryazarlık perspektifinden incelenmesi. Batı Anadolu Eğitim Bilimleri Dergisi, 10(2), 79-99. https://dergipark.org.tr/en/pub/baebd/issue/50912/645939 
Kutluk, B. (2011). ilköğretim matematik öğretmenlerinin örüntü kavramına ilişkin öğrenci güçlükleri bilgilerinin incelenmesi. [Doktora Tezi, Dokuz Eylül Üniversitesi]. Ulusal Tez Merkezi. https://tez.yok.gov.tr/UlusalTezMerkezi/

Lan, P. S., Liu, M. C. ve Baranwal, D. (2020). Applying contracts and online communities to promote student self-regulation in English learning at the primary-school level. Interactive Learning Environments, 112.

Maelasari, E. (2017). Effects of Cooperative Learning STAD on Mathematical Communication Ability of Elementary School Student. In Journal of Physics: Conference Series, 895(1), 1-6. https://doi.org/10.1088/1742-6596/895/1/012090

Mason, W. ve Watts, D. J. (2012). Collaborative learning in networks. Proceedings of the National Academy of Sciences, 109(3), 764-769. https://doi.org/10.1073/pnas.1110069108

Mumcu, H. Y. (2018). Matematiksel ilişkilendirme becerisinin kuramsal boyutta incelenmesi: türev kavramı örneği. Türk Bilgisayar ve Matematik Eğitimi Dergisi, 9(2), 211-248. https://doi.org/10.16949/turkbilmat.379891

Needleman, I. G. (2002). A guide to systematic reviews. Journal of clinical periodontology, $29,6-9$. https://doi.org/10.1034/j.1600-051X.29.s3.15.x

Olkun, S. ve Toluk Uçar, Z. (2012). ilköğretimde etkinlik temelli matematik öğretimi (5. baskı). Eğiten Kitap Yayıncılık.

Önder, F. ve Sılay, ì. (2015). İşbirlikli öğrenme yönteminin farklı öğrenme stillerine sahip öğrencilerin fizik dersi $\begin{array}{llll}\text { başarısına etkisi. Kastamonu Eğitim } & \text { 843-860. }\end{array}$ https://dergipark.org.tr/en/pub/kefdergi/issue/22599/241439

Özden, Y. (20121). Öğrenme-öğretme. Pegem Akademi.

Öztürk, G. ve Kalyoncu, N. (2018). Müziksel işitme eğitiminde kullanılan işbirlikli öğrenme yönteminin öğrenci kaygı ve başarısına etkisi. Journal of Measurement and Evaluation in Education and Psychology, 9(4), 356-375. https://10.21031/epod.411010

Rahayu, G. D. S. ve Nugraha, F. F. (2018). Effect of cooperative learning model type team game tournament (TGT) on cross-cultural skills in learning science social knowledge in primary school. PrimaryEduJournal of Primary Education, 2(1), 63-70.

Panitz, T. (1999). The motivational benefits of cooperative learning. New directions for teaching and learning, 78, 59-67.

Patton, M. Q. (2014). Nitel arastirma ve degerlendirme yontemleri. Qualitative research and evaluation methods].(Trans. Eds. M. Butun ve SB Demir). Ankara: Pegem Akademi.

Rivera-Pérez, S., Fernandez-Rio, J. ve Iglesias Gallego, D. (2021). Effects of an 8-Week Cooperative Learning Intervention on Physical Education Students' Task and Self-Approach Goals, and Emotional Intelligence. International Journal of Environmental Research and Public Health, 18(1), 61. https://doi.org/10.3390/ijerph18010061

Pawattana, A., Prasarnpanich, S. ve Attanawong, R. (2014). Enhancing primary school students' social skills using cooperative learning in mathematics. Procedia-Social and Behavioral Sciences, 112, 656-661. https://doi.org/10.1016/j.sbspro.2014.01.1214

Rojas-Drummond, S., Hernández, G., Vélez, M. ve Villagrán, G. (1998). Cooperative learning and the appropriation of procedural knowledge by primary school children. Learning and Instruction, 8(1), 37-61. https://doi.org/10.1016/S0959-4752(97)00001-7

Rowntree, E. K. (2018). Investigating the relationships between motivation, self-regulation, the learning environment, and cooperative learning in middle school classrooms in Abu Dhabi. [Doctoral dissertation, Curtin University]. http://hdl.handle.net/20.500.11937/75250

Saban, A. (2014). Öğrenme öğretme süreci (7. baskı). Nobel Yayıncılık.

Safitri, S., Dwijanto, D. ve Yusuf, A. (2020). Mathematics communication skills reviewed by emotional quotient of primary school students on circ typed cooperative learning. Educational Management, 9(1), 75-81. http://journal.unnes.ac.id/sju/index.php/eduman

Slavin, R. E. (1980). Cooperative learning. Review of Educational Research, 50(2), 315-342. https://doi.org/10.3102/00346543050002315

Slavin, R. E. (1990). Research on cooperative learning: Consensus and controversy. Educational Leadership, 47(4), 52-54.

Slavin, R. E. (2011). Instruction based on cooperative learning. Handbook of research on learning and instruction, Routledge. 
Sulisworo, D. ve Suryani, F. (2014). The effect of cooperative learning, motivation and information technology literacy to achievement. International Journal of Learning ve Development, 4(2), 58-64. http://dx.doi.org/10.5296/ijld.v4i2.4908

Şimşek, Ü., Doymuş, K. ve Şimşek, U. (2008). İşbirlikli öğrenme yöntemi üzerine derleme çalışması: II. İşbirlikli öğrenme yönteminin sınıf ortamında uygulanması. Erzincan Üniversitesi Eğitim Fakültesi Dergisi, 10(1), 123-142.

Şimşek, U., Şimşek, Ü. ve Doymuş, K. (2006). İşbirlikçi öğrenme yöntemi üzerine derleme çalışması III: işbirlikçi öğrenme yönteminin eğitim ortamındaki faydaları. Atatürk Üniversitesi Kazım Karabekir Eğitim Fakültesi Dergisi, (13), 414-430.

Sobieraj, D. M. ve Baker, W. L. (2021). Research and scholarly methods: Systematic reviews. Journal of the American College of Clinical Pharmacy, 4(7), 849-854. https://doi.org/10.1002/jac5.1440

Şen Ş. ve Yılmaz, A. (2013). İşbirlikçi öğrenmenin kavramsal değişim üzerindeki etkisi: Bir meta analiz çalışması. Karaelmas Eğitim Bilimleri Dergisi, 1(1), 21-32.

Capar, G. ve Tarim, K. (2015). Efficacy of the Cooperative Learning Method on Mathematics Achievement and Attitude: A Meta-Analysis Research. Educational Sciences: Theory and Practice, 15(2), 553-559.

Taş, G. ve Akoğlu, K. (2020). Sosyal bilgiler öğretiminde işbirlikli öğrenme yaklaşımının etkisi: meta-sentez çalışması . Türk Eğitim Bilimleri Dergisi, 18(2), 956-983. https:// 10.37217/tebd.790160

Torgerson, C. (2003). Systematic reviews. Bloomsbury Publishing.

Tuğral, Z. ve Güvenç, H. (2016). İşbirlikli Öğrenmenin Lise Öğrencilerinin Matematik Özyeterlik Algıları, Başarı ve Etkin Katılımlarına Etkileri. Ahi Evran Üniversitesi Kırşehir Eğitim Fakültesi Dergisi, 17(2), 259-274. https://dergipark.org.tr/en/pub/kefad/issue/59426/853574

Tuncer, M. ve Dikmen, M. (2017). İşbirlikli öğrenmenin başarıya etkisi: Çalışma grubu ile etki büyüklüğü arasındaki ilişkiye dair bir meta analiz çalışması. Journal of Human Sciences, 14(1), 473-485.

Turgut, S. (2018). Türkiye'de işbirlikli öğrenmenin matematik tutumuna etkisi: meta-analitik bir inceleme. Gazi Üniversitesi Gazi Eğitim Fakültesi Dergisi, 38(3), 1233-1254. https://doi.org/10.17152/gefad.401187

Tsay, M. ve Brady, M. (2010). A Case Study of Cooperative Learning and Communication Pedagogy: Does Working in Teams Make a Difference?. Journal of the Scholarship of Teaching and Learning, 10(2), 78-89.

Yaman, H. ve Umay, A. (2013). İlköğretim öğrencilerinin sunum biçimlerine göre matematiksel örüntüleri algılayışları. Hacettepe Üniversitesi Eğitim Fakültesi Dergisi, 28(28-1), 405-416. https://dergipark.org.tr/en/pub/hunefd/issue/7789/101857

Yıldııım, A. ve Şimşek, H. (2018). Sosyal bilimlerde nitel araştırma yöntemleri. Seçkin Yayıncılık.

Yıldız, E., Ağgül, Ö., Çalıklar, Ş. ve Şimşek, Ü. (2021). Eğitsel oyun ve işbirlikli öğrenmenin 6. sınıf öğrencilerinin akademik başarılarına, sosyal becerilerine ve öğrenme motivasyonlarına etkisi. Anemon Muş Alparslan Üniversitesi Sosyal Bilimler Dergisi, 8(6), https://doi.org/10.18506/anemon.671575

Yıldız, E., Şimşek, Ü. ve Ağdaş, H. (2017). Eğitsel oyun entegre edilmiş işbirlikli öğrenme modelinin öğrencilerin fen öğrenimi motivasyonları ve sosyal becerileri üzerine etkisi. Ahi Evran Üniversitesi Kırşehir Eğitim Fakültesi Dergisi, 18(2), 37-54. https://dergipark.org.tr/en/pub/kefad/issue/59416/853275

Yılmaz, M. (2007). Görsel sanatlar eğitiminde işbirlikli öğrenme. Kastamonu Eğitim Dergisi, 15(2), 747-756.

Ek1.

\begin{tabular}{|c|c|}
\hline Makale ve Tez Kodları & Kaynakça \\
\hline $\mathrm{M}_{1}$ & $\begin{array}{l}\text { Yılmaz, M. ve Top, M. (2015). İşbirlikli tartışma sorgulama (iTS) stratejisinin } \\
\text { ilkokul 4. sınıf öğrencilerinin okuduğunu anlama başarılarına etkisi. Mustafa } \\
\text { Kemal Üniversitesi Sosyal Bilimler Enstitüsü Dergisi, 12(30), 78- } \\
\text { 97. https://dergipark.org.tr/en/pub/mkusbed/issue/19576/208832 }\end{array}$ \\
\hline $\mathrm{M}_{2}$ & $\begin{array}{l}\text { Ulaş, A. H., Epçaçan, C., Aydın, S. M. ve Kurtlu, Y. (2015). ilkokul 4. sınıf } \\
\text { öğrencilerine cümlenin ögelerinin öğretiminde işbirlikli öğrenme tekniklerinden } \\
\text { takım oyun turnuvanın akademik başarıya etkisi. Turkish Studies } \\
\text { (Elektronik), 10(7), } \\
\text { https://app.trdizin.gov.tr/publication/paper/detail/TWpVME9ERTVPUT09 }\end{array}$ \\
\hline$M_{3}$ & Erbil, D. G. ve Kocabaş, A. (2015). İşbirlikli öğrenme yoluyla ilkokul üçüncü sınıf \\
\hline
\end{tabular}




\begin{tabular}{|c|c|}
\hline & $\begin{array}{l}\text { öğrencilerinin yansıtıcı düşünme becerilerinin geliştirilmesi. Uluslararası Eğitim } \\
\text { Programları ve Öğretim Çalışmaları Dergisi, 5(9), 63-79. }\end{array}$ \\
\hline $\mathrm{M}_{4}$ & 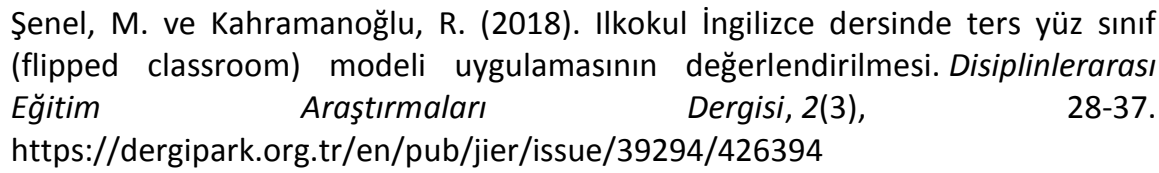 \\
\hline $\mathrm{M}_{5}$ & $\begin{array}{l}\text { Serin, M. K. ve Korkmaz, İ. (2018). İşbirliğine dayalı ortamlarda gerçekleştirilen } \\
\text { üstbilişsel sorgulama temelli öğretimin ilkokul 4. sınıf öğrencilerinin } \\
\text { matematiksel problem çözme becerilerine etkisi. Elementary Education } \\
\text { Online, } 17(2), 510-531 \text {. https://10.17051/ilkonline.2018.418893 }\end{array}$ \\
\hline $\mathrm{M}_{6}$ & $\begin{array}{l}\text { Baştürk, G. ve Bektaş, M. (2019). İlkokul 4. Sınıf Öğrencilerinin İşbirliği Kavramına } \\
\text { Yönelik Metaforik Algılarının İncelenmesi. Uluslararası Alan Eğitimi Dergisi, 5(1), } \\
\text { 72-87. https://10.32570/ijofe.535196 }\end{array}$ \\
\hline $\mathrm{M}_{7}$ & $\begin{array}{l}\text { Bilen, S. ve Açıkgöz, K. Ü. (2019). İşbirlikli öğrenmenin şarkı söyleme becerileri } \\
\text { üzerindeki etkisi. Yüzüncü Yıl Üniversitesi Eğitim Fakültesi Dergisi, 16(1), 803-817. } \\
\text { https://dergipark.org.tr/en/pub/yyuefd/issue/50700/660029 }\end{array}$ \\
\hline $\mathrm{M}_{8}$ & $\begin{array}{l}\text { Gökçe Erbil, D. ve Kocabaş, A. (2020). İlkokul 4. Sınıf Öğrencileri için Bütünleşme } \\
\text { Ölçeğinin Geliştirilmesi . Yüzüncü Yıl Üniversitesi Eğitim Fakültesi Dergisi , 17(1), } \\
\text { 700-721 . https:// 10.33711/yyuefd.710059 }\end{array}$ \\
\hline $\mathrm{T}_{1}$ & $\begin{array}{l}\text { Erdoğan F. (2015). İşbirlikli öğrenme yönteminin ilkokul 4. sınıf matematik } \\
\text { dersinde öğrencilerin akademik başarılarına ve üst bilişsel farkındalıklarına } \\
\text { etkileri. [Yüksek Lisans Tezi, Dokuz Eylül Üniversitesi]. Ulusal Tez Merkezi. } \\
\text { https://tez.yok.gov.tr/UlusalTezMerkezi/ }\end{array}$ \\
\hline $\mathrm{T}_{2}$ & $\begin{array}{l}\text { Karaaslan T. (2015). İşbirlikli öğrenmenin ilkokul 4.sınıf müzik dersinde } \\
\text { öğrencilerin ritim becerileri ve özyeterlilik algıları üzerine etkileri. [Yüksek Lisans }\end{array}$ \\
\hline & $\begin{array}{l}\text { Tezi, Dokuz Eylül Üniversitesi]. } \\
\text { https://tez.yok.gov.tr/UlusalTezMerkezi/ }\end{array}$ \\
\hline $\mathrm{T}_{3}$ & $\begin{array}{l}\text { Koç, B. (2015). İşbirlikli öğrenme yönteminin matematik dersindeki erişiye, } \\
\text { kalıcılığa ve sosyal beceriye etkisi. [Yüksek Lisans Tezi, Adnan Menderes } \\
\text { Üniversitesi]. Ulusal Tez Merkezi. https://tez.yok.gov.tr/UlusalTezMerkezi/ }\end{array}$ \\
\hline $\mathrm{T}_{4}$ & $\begin{array}{l}\text { Yılmaz, S. (2015). Din kültürü ve ahlak bilgisi dersinde işbirlikli öğrenme yöntemi. } \\
\text { [Yüksek Lisans Tezi, Ondokuz Mayıs Üniversitesi]. Ulusal Tez Merkezi. } \\
\text { https://tez.yok.gov.tr/UlusalTezMerkezi/ }\end{array}$ \\
\hline$T_{5}$ & $\begin{array}{l}\text { Kandemir, M., A. (2017). Illkokul dördüncü sınıf fen bilimleri dersinde aktif } \\
\text { öğrenme yaklaşımı doğrultusunda jıgsaw II tekniğini kullanmanın akademik } \\
\text { başarı ve kalıcılık üzerine etkisi. [Yüksek Lisans Tezi, Ondokuz Mayıs Üniversitesi]. } \\
\text { Ulusal Tez Merkezi. https://tez.yok.gov.tr/UlusalTezMerkezi/ }\end{array}$ \\
\hline $\mathrm{T}_{6}$ & $\begin{array}{l}\text { Palak, T. (2018). ilkokul 4. sınıf sosyal bilgiler dersinde kullanılan işbirliğine dayalı } \\
\text { öğrenme yöntemi birleştirme tekniğinin öğrencilerin sosyal becerilerine ve akran } \\
\text { zorbalığına etkisi. [Yüksek Lisans Tezi, Marmara Üniversitesi]. Ulusal Tez } \\
\text { Merkezi. https://tez.yok.gov.tr/UlusalTezMerkezi/ }\end{array}$ \\
\hline $\mathrm{T}_{7}$ & $\begin{array}{l}\text { Tanrıverdi, T. (2019). Illkokul ikinci sınıfta işbirlikli öğrenme yönteminin } \\
\text { öğrencilerin kelime hazinesi gelişimine ve Türkçe dersine yönelik tutumlarına } \\
\text { etkisinin incelenmesi. [Yüksek Lisans Tezi, Sakarya Üniversitesi]. Ulusal Tez } \\
\text { Merkezi. https://tez.yok.gov.tr/UlusalTezMerkezi/ }\end{array}$ \\
\hline $\mathrm{T}_{8}$ & $\begin{array}{l}\text { Alıcı, B. (2019). Jigsaw ıv tekniğinin 4. sınıf fen bilimleri dersinde öğrencilerin } \\
\text { akademik başarına ve kalııılığa etkisi. [Yüksek Lisans Tezi, Fırat Üniversitesi]. } \\
\text { Ulusal Tez Merkezi. https://tez.yok.gov.tr/UlusalTezMerkezi/ }\end{array}$ \\
\hline $\mathrm{T}_{9}$ & $\begin{array}{l}\text { Uslu, A. (2019). Iş̧birlikli dijital hikaye anlatımının ilkokul 4. sınıf öğrencilerinin } \\
\text { yaratıcı yazma ve sosyal duygusal öğrenme becerilerine etkisi. [Yüksek Lisans } \\
\text { Tezi, Manisa Celal Bayar Üniversitesi]. Ulusal Tez Merkezi. } \\
\text { https://tez.yok.gov.tr/UlusalTezMerkezi/ }\end{array}$ \\
\hline $\mathrm{T}_{10}$ & $\begin{array}{l}\text { Can, M., C. (2020). Ayrılıp birleşme tekniğinin 3.sınıf öğrencilerinin empatik } \\
\text { eğilimleri ve hayat bilgisi dersine yönelik tutumlarına etkisi. [Yüksek Lisans Tezi, }\end{array}$ \\
\hline
\end{tabular}


